\title{
1000 HPK Parenting Promotion Program in Kepulauan \\ Seribu 2018-2020: Reviewed from The Theory of Hafied \\ Cangara Communication Strategy
}

\author{
Restu Rahmawati ${ }^{1}$, Clara Cindy ${ }^{2}$ \\ 1,2 Program Studi Ilmu Pemerintahan Fakultas Ilmu Sosial dan Ilmu Politik, Universitas 17 Agustus \\ 1945 Jakarta, Indonesia (email: 1restu.rahmawati3@gmail.com)
}

\begin{abstract}
This study aims to determine about 1000 HPK Parenting Promotion Program In Kepulauan Seribu 2018-2020: Reviewed from the Theory of Hafied Cangara Communication Strategy. This type of research is descriptive research using qualitative methods. Collecting data by conducting observations, interviews, and documentation. The communication strategy carried out by the Thousand Islands PPAPP Sub-Department refers to Hafied Cangara's theory, where in this case the communication strategy in the KIE promotion program for the Care of $1000 \mathrm{HPK}$ is carried out through the first stage and then continues with planning, implementation, evaluation and reporting. The results showed that the communication strategy carried out in the 1000 HPK KIE Promotion Program was carried out through a 1000 HPK parenting training program directly face to face while practicing using the tools provided and online through webinars. In the process of implementing the program, referring to the 2018 National Priority Promotion Projection Technical Guidelines and KIE for the First 1000 Days of Life (HPK). According to Hafied Cangara's theory, the failure of the communication strategy of the 1000 HPK KIE Parenting Promotion Program for 20182020 is the absence of a research process first carried out Kepulauan Seribu Sub-Department PPAPP. 1000 HPK 2018-2020. Thus, to realize the 1000 HPK Care KIE program 2018-2020 to the fullest, a process is needed before the program is implemented so that it is right on target and the community is enthusiastic about participating in the 1000 HPK Care KIE Promotion program.
\end{abstract}

\section{Keywords:}

communication strategy; stunting; promotion program for KIE Parenting 1000 HPK

\section{Introduction}

Indonesia has succeeded in reducing the stunting problem. In 2013, stunting cases in Indonesia reached 37.2\%. Then, the Basic Health Research (Riskesdas) stated that in 2018 this stunting case managed to decrease compared to the previous year, which was $30.81 \%$ (Kemkes.go.id, 2019). In 2019 it decreased again to 27.67\% (Kabar24.bisnis.com, 2019). 
Although Indonesia has succeeded in reducing the stunting problem, its achievements still need to be continuously improved because the World Health Organization (WHO) standard sets a 20\% stunting case limit standard (CNN Indonesia, 2017). Stunting is also a serious public health problem in developing countries (Indriani \& Retno, 2018) Stunting refers to the condition of a child's height that is shorter than his age, caused by a lack of nutritional intake for a long time in the first 1000 days of life (HPK). As adults, children are vulnerable to attacks from non-communicable diseases such as heart disease, stroke, diabetes, or kidney failure; hampering Indonesia's demographic bonus where the ratio of the non-working age population to the working age population decreases; threat of reducing intelligence level by 5-11 points. In addition to nutritional factors, stunting is caused by a lack of public knowledge, especially pregnant women, mothers of toddlers and posyandu cadres about stunting (Astuti, 2018) Information Communication and Education Promotion Program (KIE) Parenting for the First 1000 Days of Life itself aims to improve the knowledge, skills, attitudes, and behaviors of parents, families with children under the age of five, pregnant women, and expectant mothers regarding child care and development in the first 1000 Days of Birth to prevent stunting.

Various efforts have been made by the Government of Indonesia to continue to reduce stunting cases. One of the programs carried out for health development and preventing stunting is the First 1000 Days of Life (HPK) program which is stated in the Presidential Regulation of the Republic of Indonesia Number 42 of 2013 concerning the National Movement for the Acceleration of Nutrition Improvement. This 1000 HPK KIE Promotion Program is carried out by the Department of Empowerment, Child Protection and Population Control (DPPAPP). Department of Empowerment, Child Protection and Population Control (DPPAPP) to carry out their duties and functions assisted by the SubDepartment for Empowerment, Child Protection, and Population Control (Suku Dinas PPAPP) who are in each city of DKI Jakarta in preventing stunting in each city of DKI Jakarta.

The data from the 2018 basic health research on the proportion of nutritional status in the 2013-2018 provinces explains that the province in Indonesia with the highest stunting problem is Nusa Tenggara Timur. Nusa Tenggara Timur Province has a high prevalence of stunting in children aged 0-23 months of $29.8 \%$. According to the NTT Health Office, the percentage of stunting in children aged 0-23 months in Kupang, the capital of NTT province, 
is $25 \%$ (Ilma et al., 2019) while the lowest proportion of stunting cases is DKI Jakarta Province. DKI Jakarta with the lowest proportion of stunting cases, it turns out that there are still areas in DKI Jakarta that still have a high stunting rate, namely the Thousand Islands. All areas in DKI Jakarta should have lower stunting cases, however, the Kepulauan Seribu still have a high rate of stunting cases while DKI Jakarta is one of the provinces with the lowest stunting cases in Indonesia. This is then what we want to explore why the Kepulauan Seribu still has a high rate of stunting cases. In addition, the Kepulauan Seribu is also one of the priority loci of stunting reduction set by Badan Perencanaan Pembangunan Nasional (BAPPENAS).

The focus to be seen is the communication strategy of the relevant agencies to increase the success of the 1000 HPK KIE Promotion program based on Hafied Cangara's theory of communication strategy which consists of 5 indicators, namely research, planning, implementation, evaluation, reporting indicators. The reason the author uses the Hafied Cangara theory is because in literature there is no study of communication strategy using the Hafied Cangara approach and most of the previous studies have not used Hafied Cangara. Therefore, this study examines how the communication strategy of Kepulauan Seribu Sub-Department PPAPP is related to stunting prevention through the KIE promotion program for the care of 1000 HPK 2018-2020; and how are the obstacles faced by Kepulauan Seribu Sub-Department PPAPP service tribe in carrying out communication strategies in stunting prevention through the promotion program for the 1000 HPK parenting KIE 20182020.

\section{Methods}

Judging from the type of data, the research approach used in this study is a qualitative approach. Qualitative research is a special research object that cannot be examined statistically or quantified to understand by describing it in the form of words and language according to Basrowi and Kelvin (Suwandi, 2008). Where this type of research uses descriptive research. Descriptive method, namely research that aims to describe as accurately as possible about something that is a particular object, symptom or group and to answer questions about phenomena and events that are currently happening. (Sugiyono, 2009). Data collection techniques used in this study were interviews and observation. 


\section{Results and Discussion}

The KIE promotion program for the care of 1000 HPK started with the Presidential Regulation of the Republic of Indonesia Number 42 of 2013 concerning the National Movement for the Acceleration of Nutrition Improvement which aims to accelerate the improvement of community nutrition with priority in the First 1000 Days of Life. The Promotion of Information Communication and Education (KIE) Program for Care for the First 1000 Days of Life itself aims to improve the knowledge, skills, attitudes, and behaviors of parents, families with under-fives, pregnant women, and expectant mothers regarding child care and growth in the 1000-day period. First Birth to prevent stunting. This goal is carried out through physical, motor, intelligence, social, emotional and moral stimulation that takes place in the interaction process.

The target of the KIE promotion program for the care of 1000 HPK is pregnant women and mothers with two year old toddlers (baduta). In 2018, the target given to Kepulauan Seribu Sub-Department PPAPP was 893 targets and was fully realized. Then, in 2019 it was trusted with the same target (893 targets) to be given counseling and in 2020 the target was 983 targets. Message delivered by the Family Mobilization and Resilience field (PK2), PKB in the Kepulauan Seribu, poktan cadres, dasawisma, PKK, PKKBB, and PKBRW as managers and implementers in the field have the goal of giving the desired effect to the communication target. The effect is to increase parents' knowledge about the importance of caring for $1000 \mathrm{HPK}$, family care when pregnant women or two year old toddlers (baduta), healthy lifestyle so that it can be applied in the family. In the implementation of the communication strategy, the success of effective communication activities is determined by the determination of the communication strategy. To discuss how the communication strategy of Kepulauan Seribu Sub-Department PPAPP in the implementation of the KIE promotion program for the care of $1000 \mathrm{HPK}$, the researcher refers to the theory according to Hafied Cangara, that the communication strategy is carried out through the stages of research, planning, implementation, evaluation, and reporting. (Cangara, 2013).

The first indicator in communication strategy according to Hafied Cangara is research. The importance of this research is to see the problems in the field so that the program made is right on target. In addition, this research strategy is carried out to find the problems that will be faced so as to produce good strategy formulation materials and plan 
what needs to be provided for the 1000 HPK IEC promotion program and determine how to distribute it.(Khoeroh et al., 2017). However, in the implementation of the research strategy, the Thousand Islands PPAPP Sub-Department was not carried out when formulating the IEC promotion program for the care of 1000 HPK 2018-2020. In the implementation of the program, Kepulauan Seribu Sub-Department PPAPP is guided by the technical guidelines made by the National Population and Family Planning Agency. (BKKBN) related to the promotion of KIE for nurturing 1000 HPK 2018-2020. The impact of not carrying out the research process first in the communication strategy of Kepulauan Seribu Sub-Department PPAPP. in the promotion program for the 1000 HPK KIE, namely the implementation of the program makes it less than optimal because it is only based on technical instructions from the BKKBN and the Seribu Islands PPAPP Sub-Department cannot directly improve the program if the program is carried out. still need updates in accordance with the conditions in the field. The second indicator is planning which includes the communicator, message, media, target (communicant), and the desired effect. Communicator as a messenger to the target of communication. The role of the communicator is an important step in developing a communication strategy. In this step the communicator must have the attractiveness and credibility of the source balanced with a sense of empathy for the communication target. In the implementation of the KIE promotion program for the care of $1000 \mathrm{HPK}$ the communicator is in the field of Family Mobilization and Resilience (PK2), PKB in the Thousand Islands, poktan cadres, dasawisma, PKK, PKKBB, dan PKBRW as managers and implementers in the field must have attractiveness and credibility. To build the attractiveness and credibility of the appointed communicator, namely the field of Family Mobilization and Resilience (PK2), PKB in Kepulauan Seribu, poktan cadres, dasawisma, PKK, PKKBB, and PKBRW as managers and implementers in the field before carrying out their duties they are given training first as a debriefing to disseminate information and procedures for the implementation of the KIE promotion program for the care of $1000 \mathrm{HPK}$.

Based on the results of the study, if you look at the role of communicators in the implementation of the KIE promotion program for the care of $1000 \mathrm{HPK}$, the public's assessment of the delivery of the message is very good because the information given by the message reaches the audience in providing directions to improve the quality of child care in 
the first 1000 days of life. Messages will fail to be understood if communication goes badly and the selection of communication strategies is not appropriate (Mona Ganiem, 2019)

At the stage of determining the message, the message can attract attention if the message concerns the needs and interests and is useful for the communication target. Based on the results of the study, the message conveyed by Kepulauan Seribu Sub-Department PPAPP in the implementation of the KIE promotion program for the care of $1000 \mathrm{HPK}$ was in the form of a verbal message. Verbal messages conveyed in the form of oral and written. Oral messages are carried out during program implementation directly face to face between the implementer and the recipient of the message or target. This verbal message is also carried out with additional practice of stimulating ways using educational game tools. The message conveyed through the KIE promotion program for nurturing $1000 \mathrm{HPK}$ is information on how to stimulate children during pregnancy and after birth to produce healthy, intelligent and characterful children, the role of fathers or husbands when the child is in the womb or already born, and mental and physical health. while pregnant and breastfeeding. Materials or messages conveyed by the Family Mobilization and Resilience field (PK2), PKB in the Thousand Islands, poktan cadres, dasawisma, PKK, PKKBB, and PKBRW as managers and implementers in the field are carried out based on technical guidelines for priority promotion projects and KIE for the First 1000 Days of Life (HPK) in 2018 and 2019.

The delivery of the right message is also influenced by the media used. The media used to convey the message must be in accordance with the characteristics and objectives of the message content and the media owned by the communication target. Kepulauan Seribu Sub-Department PPAPP is to be able to reach the dissemination of information regarding the delivery of messages for the promotion of the KIE for the care of 1000 HPK through group and individual meetings directly in every village in Kepulauan Seribu and online through social media, such as Instagram, Facebook, YouTube, and zoom meetings in the form of webinars. Not only online media is used in delivering the material, but also the delivery of material using flashback books (pictures back and forth) and posters The use of social media as said by executor, on In fact, not all of the social media mentioned are used in the implementation of the program. One of them on Facebook was that no materials or messages were found regarding the KIE promotion program for the care of $1000 \mathrm{HPK}$. In 
addition, flashback books and posters can only be found if the program is implemented faceto-face or face-to-face. In Kepulauan Seribu, POKTAN, cadres, dasawisma, PKK, PKKBB, dan PKBRW as managers and implementers in the field are said to have succeeded in achieving the targets that have been set given for the implementation of the KIE promotion program for the care of 1000 HPK. The KIE promotion program for the care of $1000 \mathrm{HPK}$ carried out by the Kepulauan Seribu Sub-Department PPAPP from 2018 to 2019 was carried out directly face to face through group meetings.

The third indicator in the communication strategy according to Hafied Cangara is implementation. Implementation is the step of implementing the communication strategy for the KIE promotion program for the care of $1000 \mathrm{HPK}$ that has been formulated previously. The implementation of the program is carried out in accordance with predetermined plans starting from the communicator, the message to be conveyed, the target of the program implementation, the media used to convey the message and the desired effect of the message. Family and Individual Mobilization and Resilience. Then, in 2020, during the Covid-19 pandemic, Kepulauan Seribu PPAPP Sub-department began to focus on online media. Where the implementation is carried out by holding a webinar through a zoom meeting. The webinar is also uploaded to YouTube so that the public can review the materials provided during the webinar. Through online media, the scope of program implementation is wider so that not only pregnant women and mothers with two-year-old toddlers (baduta) who attend the webinar can see, but other people who are not included in the target can see and learn about the care of 1000 HPK.

The implementation of this program is very beneficial for pregnant women and mothers of two-year-old toddlers (baduta) because with this program the community understands that the care of $1000 \mathrm{HPK}$ is very important to prevent stunting and the pattern of parenting for children to change for the better. From this research, the researcher sees that the material provided in this program is quite complete and can add to the knowledge of parenting 1000 HPK. Not only about the care of 1000 HPK but also about the impact of HIV and Aids on 1000 HPK. The response from the community with this program is also very good regarding the delivery of messages that are easy to understand, the material is very useful, even the community provides input for the implementation of the program that can be carried out every month so that the community or those who need knowledge of caring 
for $1000 \mathrm{HPK}$ get it and there is also input for targets not only to pregnant women and mothers of two-year- old toddlers (baduta), but broaden the target to young newly married mothers and mothers who are preparing to have children.

Not only about the care of 1000 HPK but also about the impact of HIV and Aids on $1000 \mathrm{HPK}$. The response from the community with this program is also very good regarding the delivery of messages that are easy to understand, the material is very useful, even the community provides input for the implementation of the program that can be carried out every month so that the community or those who need knowledge of caring for $1000 \mathrm{HPK}$ get it and there is also input for targets not only to pregnant women and mothers of twoyear-old toddlers (baduta), but broaden the target to young newly married mothers and mothers who are preparing to have children. Changes after being given counseling or parenting training for $1000 \mathrm{HPK}$. At the evaluation stage based on the strategic management process, evaluation is a process of assessing the results of the performance of program implementers by looking at the implementation of the strategy and comparing it with the expected performance so that it can be seen whether the current strategy is going well or needs changes. From the research results of the Kepulauan Seribu Sub-Department PPAPP in implementing this program, it is still not good at evaluating communication strategies because it only relies on reports after program activities are completed.

Kepulauan Seribu Sub-Department PPAPP does not yet have a special application or forum for evaluating program strategies. The special application or forum for evaluating is very important and facilitates the implementation of evaluation so that the communication strategy for the implementation of the next program can be better than before. Kepulauan Seribu Sub-Department PPAPP also does not have a place to submit criticism or suggestions from the target of the KIE promotion program for the care of 1000 HPK. The program target can only provide criticism or suggestions directly to the implementers in the field. This criticism or suggestion is very important in the evaluation of the program so that the communication strategy in implementing the next program can meet the needs and desires of the target of the 1000 HPK KIE promotion program. The last indicator, namely reporting. The form of reporting carried out by Kepulauan Seribu Sub-Department PPAPP with reporting on each activity and every month. The activity report can be in the form of activity minutes as a complementary archive document for the administration of activities. Report 
as evidence of the KIE promotion program activities for the care of $1000 \mathrm{HPKs}$ that have been carried out by the Kepulauan Seribu Sub-Department PPAPP. Reports are submitted to the $\mathrm{BKKBN}$ and through the BAPPENAS monitoring and evaluation application. The report contains the number of targets that have been achieved and the realization of activities. This report is carried out to see whether the activities are running according to the plans that have been made or less than optimal in their implementation.

In addition to conducting an evaluation, this report can also be taken into consideration by the Kepulauan Seribu Sub-Department PPAPP in subsequent activities. Currently the government is encouraged to develop and implement E-government based on Presidential Instruction No. 3 of 2003 on National Policy and Strategy for E-government Development, but Kepulauan Seribu PPAPP Sub-department in making reports is still manual. So, Kepulauan Seribu Sub-Department PPAPP should carry out the development of E-government in reporting the KIE promotion program for the care of $1000 \mathrm{HPK}$ to be more effective, efficient and transparent. With reporting through E-government, all information on activities that have been carried out are stored properly. This makes it easier if you need previous data to be searched and found.

The obstacles of Kepulauan Seribu Sub-Department PPAPP in implementing the stunting prevention communication strategy through the KIE promotion program for the care of 1000 HPK 2018-2020 were experienced in 2020 due to the covid-19 pandemic. Although previously also using online media, but not entirely done online. So, in 2020 Kepulauan Seribu Sub-Department PPAPP starts holding webinars through zoom meetings. In the webinar, many obstacles are encountered because the two-way communication webinar is not fully implemented. The spirit of mothers is more inclined to face-to-face training or counseling. The community mostly only listens to the material presented by the resource person regarding the care of $1000 \mathrm{HPK}$, cannot directly submit complaints or questions they want to ask.

According to the results of the study, the obstacles faced when offline or face-to-face were regarding the presence of fewer BKB mothers than their students and the number of face-to-face implementations was more limited than the online implementation which could cover more targets in one meeting. With the training webinar not being able to directly practice the materials that have been given, it is difficult to see if the materials provided are 
also carried out by the community. In addition, if there are people who still do not understand technology, the implementer must provide a place to be able to view the webinar together. In the Thousand Islands, it is also undeniable that the signal is sometimes a bit difficult, thus hampering webinar activities. The webinar is held for more than 2 hours causing boredom so that people don't focus on receiving webinar material. Basically, every program or policy implementation has obstacles that must be faced in its implementation, both internal and external constraints. To add enthusiasm and reduce existing obstacles, participation and cooperation from the Family Mobilization and Resilience Sector (PK2), PKB in Kepulauan Seribu, Poktan, Dasawisma, PKK, PKKBB, and PKBRW cadres are needed as managers and implementers in the field with pregnant women or children under two. which is the target in the implementation of the program so that the implementation can be well coordinated and in accordance with the objectives.

\section{Conclusion}

Based on the results of the study, it was shown that the communication strategy of Kepulauan Seribu Sub-Department PPAPP in preventing stunting through the KIE promotion program for the care of 1000 HPK 2018-2020 seen by the five stages of the communication strategy according to Hafied Cangara, did not fulfill the five stages. The first stage that must be carried out by the Thousand Islands PPAPP Sub-Department is research. However, the Thousand Islands PPAPP Sub-Department did not conduct previous research before implementing the KIE promotion program for the care of $1000 \mathrm{HPK}$. This first stage affects the next stage of communication strategy. Kepulauan Seribu Sub-Department PPAPP continues to rely on technical guidelines for national priority promotion projects and KIE for the First 1000 Days of Life (HPK). This can be seen at the evaluation and reporting stages. Kepulauan Seribu Sub-Department PPAPP does not have a special application or platform for the KIE promotion program for the care of 1000 HPK, but is only obliged to submit reporting to the BKKBN and reporting through the BAPPENAS monitoring and evaluation application. So, the communication strategy carried out by the Kepulauan Seribu SubDepartment PPAPP can be considered less than optimal.

Kepulauan Seribu Sub-Department PPAPP faces several obstacles in the implementation of the KIE promotion program for the care of $1000 \mathrm{HPK}$ in the context of 
stunting prevention, namely the Kepulauan Seribu PPAPP Sub-Department needs to change the implementation of the program directly to online media due to the covid-19 pandemic, during the webinar implementation there is no communication in a two-way manner, which sees the spirit of the target mothers more inclined to direct implementation because they can practice the material provided, the community cannot directly submit complaints or questions regarding the care of $1000 \mathrm{HPK}$, it is difficult to see whether the training or materials provided through webinars carried out into their daily activities, and the most basic obstacle faced was the signal in Kepulauan Seribu which was rather difficult to obtain.

\section{References}

Astuti, S. (2018). Gerakan Pencegahan Stunting Melalui Pemberdayaan Masyarakat Di Kecamatan Jatinangor Kabupaten Sumedang. Dharmakarya, 7(3), 185-188. https://doi.org/10.24198/dharmakarya.v7i3.20034

Cangara, Hafied. 2013. Perencanaan dan Strategi Komunikasi. Depok : PT Raja Grafindo Persada

Ilma, N. N., Salimo, H., \& Pamungkasari, E. P. (2019). Prevalence and Path Analysis on the Effects of Diarrhea and Life Course Determinants on Stunting in Children Under Two Years of Age in Kupang, East Nusa Tenggara. Journal of Maternal and Child Health, 4(4), 230-241. https://doi.org/10.26911/thejmch.2019.04.04.02

Indriani, D., \& Retno, Y. (2018). Prenatal Factors Associated with the Risk of Stunting. 4, 294-300. Khoeroh, H., Handayani, O. W. K., \& Indriyanti, D. R. (2017). Evaluasi Penatalaksanaan Gizi Balita Stunting Di Wilayah Kerja Puskesmas Sirampog. Unnes Journal of Public Health, 6(3), 189. https://doi.org/10.15294/ujph.v6i3.11723

Normaisa. Strategi Dinas Kesehatan Dalam Menekan Laju Penderita Stunting Di Kabupaten Enrekang. Fakultas Ilmu Sosial dan Ilmu Politik, Universitas Muhammadiyah Makassar, 2020.

Pratiwi, Soraya Ratna. 2019. Manajemen kampanye komunikasi kesehatan dalam upaya pengurangan prevalensi balita stunting. Jurnal Manajemen Komunikasi, Vol 4, 119. 
Priyono. 2020. Strategi Percepatan Penurunan Stunting Perdesaan (Studi Kasus Pendampingan Aksi Cegah Stunting Di Desa Banyumundu, Kabupaten Pandeglang). Jurnal Good Governance, Vol 16, No. 2.

Purba, Sri Hajijah. Analisis Implementasi Kebijakan Penurunan Stunting Di Desa Secanggang Kabupaten Langkat. Fakultas Kesehatan Masyarakat, Universitas Islam Negeri Sumatra Utara, 2019

Rahmawati, Luluk Atmi, Fathinah Ranggauni Hardy, dan Ayu Anggraeni Dyah Purbasari. 2020. Faktor-Faktor Yang Berhubungan Dengan Stunting Sangat Pendek Dan Pendek Pada Anak Usia 24-59 Bulan Di Kecamatan Sawah Besar. Jurnal Ilmiah Kesehatan Masyarakat, Vol $12(2)$.

Rosha, Bunga CH, dkk. 2016. Peran Intervensi Gizi Spesifik dan Sensitif dalam Perbaikan Masalah Gizi Balita di Kota Bogor. Jurnal Buletin Penelitian Kesehatan, Vol. 44 (2).

Silpia, Febi Rama. Pemberdayaan Masyarakat Dalam Penanggulangan Stunting (Gangguan Pertumbuhan Pada Anak) Didesa Pancasila Kecamatan Natar Lampung Selatan. Fakultas Dakwah dan Ilmu Komunikasi, Universitas Islam Negeri Radin Intan Lampung, 2019 Sugiyono. 2009. Metode Penelitian Administrasi. Bandung : Alfabeta. Suwandi, B.\&. 2008. Memahami Penelitian Kualitatif. Jakarta : Rineka Cipta. 